\title{
Sustaining the Culture of the City: Architecture and Cosmology in the Mantingan Mosque and Cemetery Complex in Jepara
}

\author{
Allifna Lie Ulin Nuha ${ }^{1}$ and Yulia Nurliani Lukito ${ }^{1 *}$ \\ ${ }^{1}$ Department of Architecture, Faculty of Engineering, Universitas Indonesia, Depok
}

\begin{abstract}
This paper analyzes the architecture of the Mosque and the Cemetery Complex of Mantingan, in Jepara, Central Java. It is the basic idea in this paper that traditional local building philosophy may help to create cultural and social sustainability. The organization of the city especially shown at the city mosque and the cemetery reflect the culture of people live in the city and understanding the organization of the complex means sustaining the culture and the history of the city. The study will focus on understanding the connection of the architecture of the mosque and the cemetery complex in relation to Javanese architecture and cosmology. Based on this analysis, the finding of this paper is that theMantinganMosque and the Cemetery Complex adopted Javanese architectural forms and cosmology in the organization of the complex and help to sustain cultural, social and economic of the city.
\end{abstract}

\section{Introduction}

Mantingan Mosque is one of the old Javanese mosques located in Jepara, Central Java. Built in 1559 during the reign of Ratu Kalinyamat, the architecture of the mosque resembles Javanese architecture including the idea of cosmology. Next to the mosque was a cemetery complex, also known as the burial ground of Sunan Hadlirin, the husband of Ratu Kalinyamat, as the key figure in the spreading of Islam in Jepara. In addition to Javanese architecture, the mosque and the cemetery complex also shows some influence of Hindu culture from earlier time.

Sustainability in the city is related to the continuous way of life across the four domains of ecology, economics, politics and culture. The arrangement of space in the city may be related to the conscious and balance development and the success of the sustainability may be seen from how local people want to conserve the city space and how the city attract visitors. Up to now, the Mantingan Mosque and cemetery complex are one of important tourist destinations in Jepara which not only symbolize strong local values but also the sustainable history, architecture and culture. Kenneth Frampton (1983) states the importance of vernacular architecture is not limited to sentimental regionalism but, when carefully analyzed, should show responses of balancing build environment with local cultures and a creation of "a place-conscious poetic". It is important to see how cosmology plays a role in the architecture of the in Mantingan Mosque and the cemetery complex as well as examining the relations among architecture, history and culture that shows how local values helps to sustain the history of the city. This paper aims to see how the role of cosmology and culture influences to be one aspect that is considered and continues to be preserved.The Mantingan Mosque and cemetery complex are examples of how traditional local building philosophy and techniques may help to create cultural and social sustainability.

\section{Methods}

Methods for the study uses descriptive and qualitative approach. First, literature studies and site visits are conducted to get the information needed for the discussion. Then, an analysis of the architecture and the cemetery complex are conducted to get the connection between architecture, cosmology and the arrangement of the Mosque and the cemetery complex.

\section{The Results and Discussions}

The Mantingan Mosque and Cemetery Complex is located in Mantingan Village, approximately four kilometer south of Jepara. The mosque in Mantingan is different from other old Javanese mosques that has a plaza (alun-alun), a government center, a market, and a Chinatown or pecinan[7]. Jepara also has typical Javanese elements of the city such us the city square or alun-alun, a market, a central government building or keraton complex and settlements that includes indigenous, Arab and Chinese people. All of those aspects in the city play an important role in the development of Jepara.

*Corresponding e-mail: yulianurliani@yahoo.com 


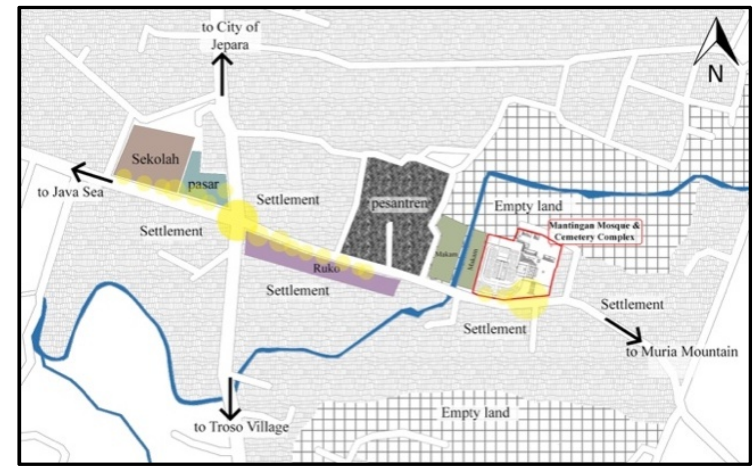

Fig. 1 Master plan of Mantingan Mosque and Cemetery Complex. Source: authors.

Depicted in Figure 1 is the location of the Mantingan Mosque that is surrounded by settlements. Unlike other old mosques in Java,the Mantinganmosque is not located near alun-alun - or called isolated mosque. This mosque is directly connected to the cemetery complex, an influence that may be come from Hindu-Java tradition[1-2]. The location of the mosque was chosen by the Sultan Hadlirinbecause he wanted to have a sacred place for worship.

The mosque bears an important role in the spread of Islam in Jepara as well as in the sustainability of the city. The mosque, which symbolizes a spiritual space, is a counterweight to the central public space or alunalun. This basic arrangement of the city has been developed even before Islam came to Java. The continuation of typical Javanese city as the structure of Jepara city means the city has sustained various social and cultural changes.

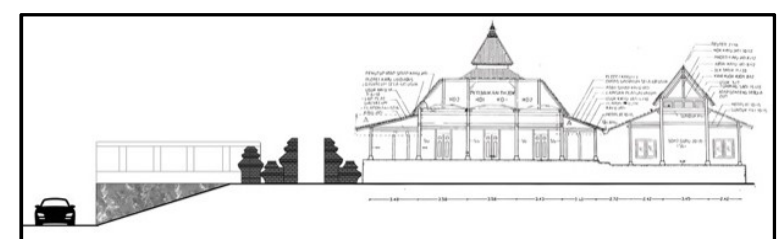

Fig. 2Elevation of Mantingan Mosque, source: author

Figure 2 presents a sectional drawing showing the position of the mosque. Not only the position of the mosque follows is higher than its surroundings, but also if follows the sea-mountain axis in Javanese cosmology. A sacred place is commonly put in higher position than a profane one. The higher position of the mosque also indicates the importance of the mosque as a place of connection with the God [5].

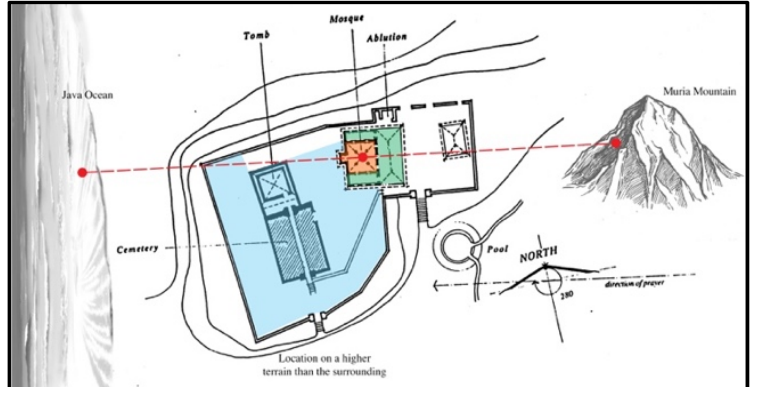

Fig. 3 Siteplan of Mantingan Mosque and Cemetery Complex, and Its Orientation with The Mountain-Sea Source: authors

The idea of cosmology, which involves the study of the world order, in traditional life means giving people fundamental sense of where they come. In Javanese society, the idea of cosmology is part of an adaptation of mandala into the Javanese culture and articulated in the concept of mancapat or the axis mundi of earth and sky [6]. The organization of important spaces follows the north-south axis with the north is the location of the mountain and the south is the location of the see. In this way, the concept of duality is part of the cosmos and power as well as arranging places according to the level of sacredness.

\subsection{The Mantingan Mosque}

The Mantingan Mosque functionsasa place of worship as well as a place to do many communities' activities. This mosque is the center for community activities and in relation to sustainability the mosque gives benefits to local people and improve the quality of life [9]. Many tourists come to Mantingan Mosque and cemetery complex and this means the complex supports local economy.

Vernacular architecture is characterized by its compactness of form and efficient utilization of land and building ecology which has many environmental, economic and social advantages to communities. The architecture of the Mantingan Mosque are four important elements of the Javanese mosque: main prayer hall, roof, mihrab or the place for imam, and the main pillars or soko guru [3].

The main prayer hall has a typical of HinduJavanese square plan.Mihrabis located on the western side of the mainprayer hall facing the direction of ka'bah. The main prayer hall implements the dual division in Javanese cosmology such as reflecting inside-outside and sacred-profane. The development of the mosque shows a proportional development to three sides of the main prayer hall and only recently an additional veranda is built to accommodate more prayers. Although the existing balance and duality in the mosque is disturbed, this development shows an effort to support the sustainability of the mosque as the place of communities' activities. 


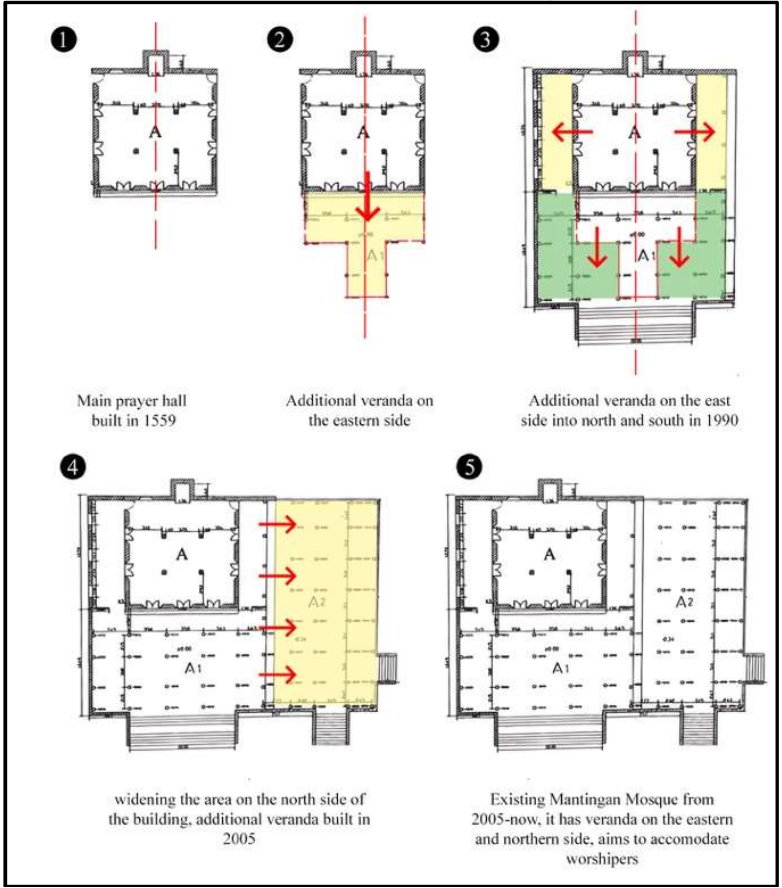

Fig.4The development of the main prayer hall at the Mantingan Mosque.Source: authors.

A roof is the most significant element that gives the identity for a Javanese mosque. The roof for the main prayer hall and the veranda is actually apendopo, although both rooms look similar but they actually have different shapes. The main prayer hall usually has three pyramidal stacked-roofs that may represent the roof of the Hindu worship place. The height of the roof creates a vertical form resembling cosmological connection to divinity and also symbolizes the importance of God. The roof is supported by four main pillars located at the centre of the main prayer hall and known as soko guru [8].There are gaps between different roof forms that allow air to circulate. The open veranda also acts like sun-shading for the main prayer hall. Moreover, the mosque also has windows to ensure good cross ventilation.

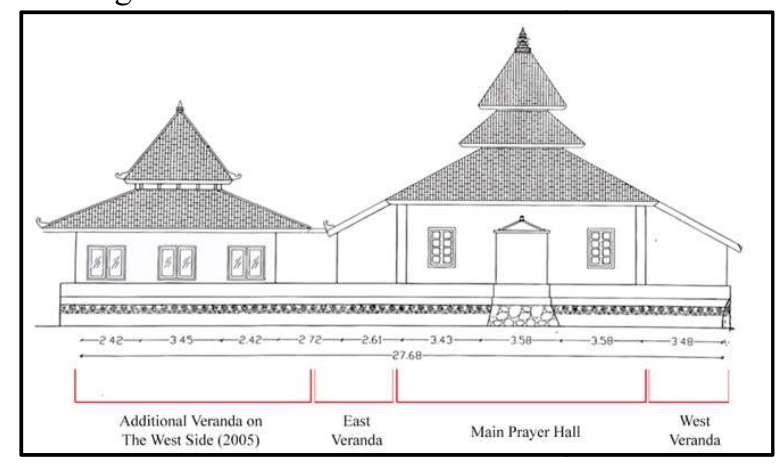

Fig. 5 East Side of The Mantingan Mosque.Source: authors.

The veranda usually has two pyramidal stackedroofs, higher than the roof a Javanese house but lower than the mosque. However, the shape of the roof for the veranda is also a pyramidal that still reflects the importance of the veranda to support religious activities.

The mosque uses local materials with environmentally friendly technologies for the building. The Mantingan Mosque is mostly made of red brick and woods, easily found in Jepara. There are some relief on the wall. In every field there are seven wall relief panels arranged from top to bottom. Depicted on these panels are mostly geometrical and plants ornaments that show Hindu influences.

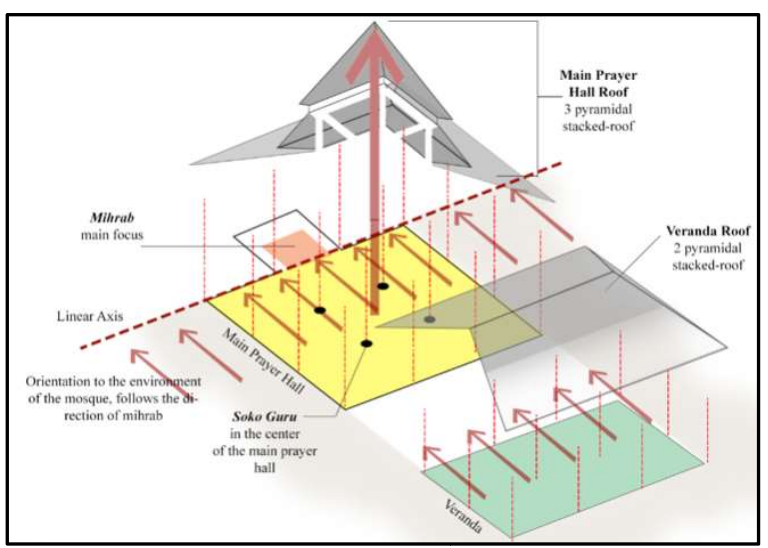

Fig. 6The concept ofmihrab as the main orientation in the complex. Source: authors.

Mihrab is a place located on the front part of the main prayer room and dedicated to the imam who leads prayers. It serves as a focus point for the mosque and helps to give direction to the ka'bah. The regularity in the mosque is symbolized by mihrab. The mosque is then a microcosm from the ka'bah while the ka'bah acts as a regulator for the microcosm [4]. People who want to pray certainly make mihrab as its main orientation, hence, the axis of the qibla is the symbolic line for the congregation to pray.

The intersection between the qibla axis and the mihrab-ka'bah axis seen in Figure 7, is in accordance with the concept of duality in Javanese cosmology. The east-west axis as the axis of the mihrab-ka'bah describes the terrestrial force, the energy of human life processes on earth, from birth to death. And the northsouth axis as the qibla axis depicts celestial force of the life and the afterlife. 


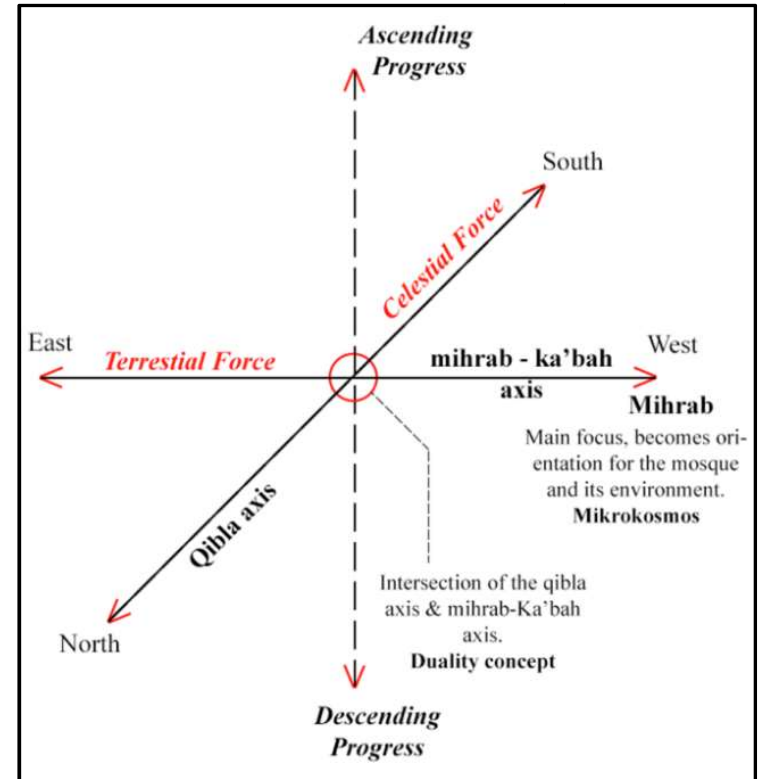

Fig. 7 Duality concept of cosmology in the mihrab and haram. Source: authors.

The joglo roof of Javanese house is supported by four principal pillars called soko guru. The principal structure of theMantingan Mosque is the four main pillars called soko guru locatedat thecenter of the main prayer hall. The veranda differs from the mosque because it only has simple roofs that are supported by wooden pillars known as sokomajapahit.

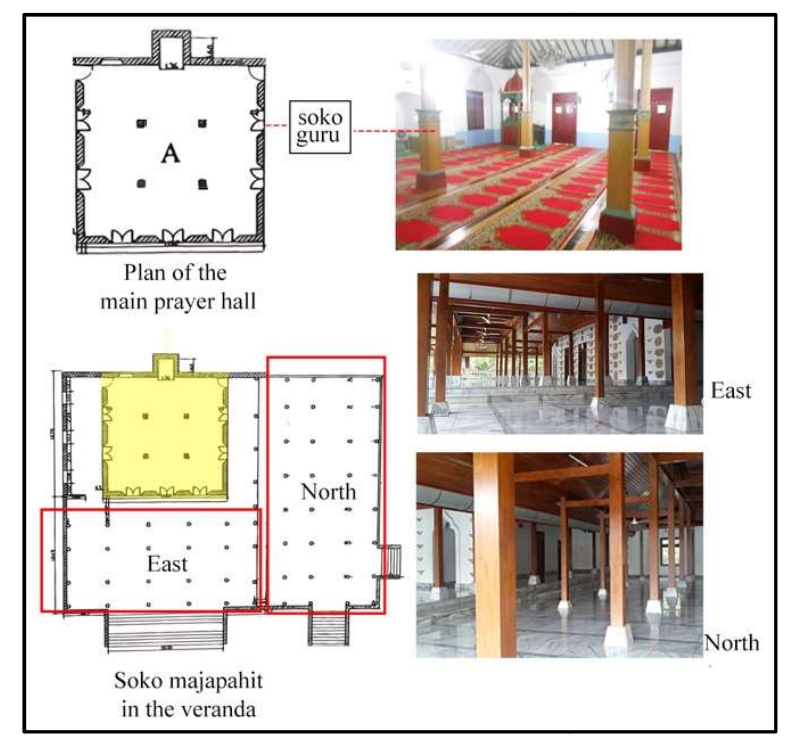

Fig. 8Soko guru and sokomajapahit of the Mantingan Mosque. Source: authors.

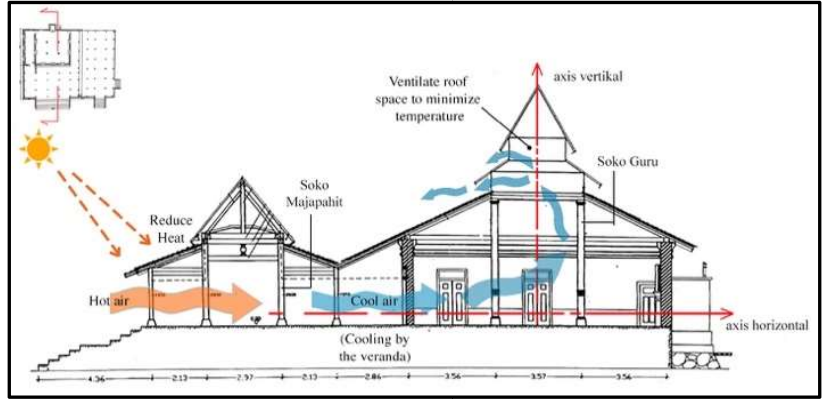

Fig. 9 South Elevation of Mantingan Mosque. Source: authors.

Soko guru provides an affirmative accent to the vertical axis depicted by the roof. The soko guru structure becomes the center that balances the mihrabka'bah axis and qibla axis. The axis of the mihrabka'bah is strengthen by the soko guru structure, so that the axis starts from the veranda-soko guru-mihrabka'bah.

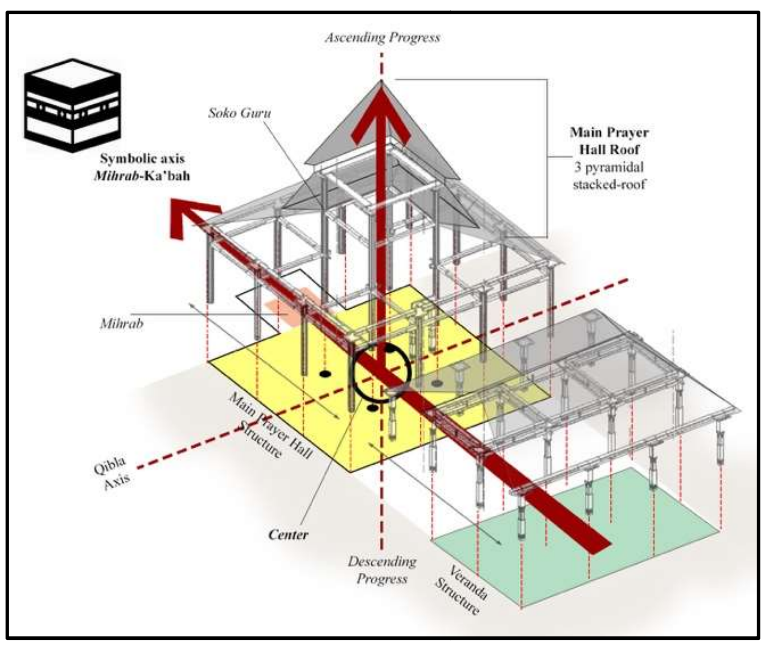

Fig. 10Structure of The Main Prayer Hall and Veranda, and Axis Formed in Accordance with Cosmology, source: author

The organization of the mosque, main prayer hall, roof, mihrab, and the soko gurustructure creates a unity and in line with Javanese cosmology. Not only the roof becomes a significant element symbolize the sacred place but also the relation of each architectural elements to cosmology make theMantingan Mosque a place that has sacred value for Mantingan society. Moreover, the open structure for the mosque creates good air ventilation and allow sun lights to enter the room.

\subsection{The Mantingan Cemetery Complex}

This cemetery complex is located on the western side of the mosque, right in front of the mihrab. The first tomb belongs toSunanJepara, and then Ratu Kalinyamat buried her husband Sultan Hadlir in next to the firsttomb. Over the time some tombs belong to 
Sultan Hadlirin's family members are added and nowadays the area becomes public cemetery.

The cemetery complex seems to have a hierarchy created by the contour. There are five different levels. The first level has the lowest contour and this area becomes a place for the latest graves, marked by the existing grave stone bearing the name and year of the death. The second level has a higher contour divided from the first level by a path for visitors. The third level has fences and the graves belong to the fifteenth century. In order to enter the third level, one has to purify themselves with water.

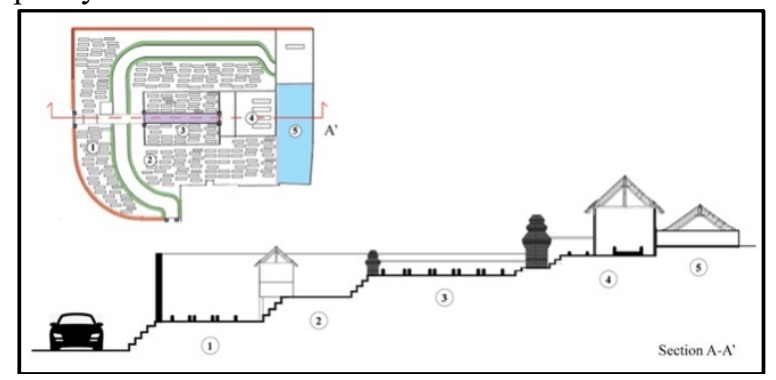

Fig. 11Siteplan\&Level Contour Elevation in Mantingan Cemetery. Source: authors.

The fourth level is the location of Sultan Hadlirin and his family's graves. The fifth level is the highest one and Mantingan people believe that no new grave should be placed in front of the Sultan grave, as a sign of honouring him as a person who spread Islam in Java. The hierarchy reminds us of hierarchy in Hindu temple before Islam came to Java. The sacred area is placed higher than the profane area.

The mosque often used as a destination for people to visit graves or pilgrims who want to pray close to Sultan's family grave. At first, the area for the mosque was a place of worship for the Sultan's family. Later on, with many graves are added, then complex functions as a destination for pilgrims.

The tomb of Sunan Jepara and the family of Sultan Hadlirin which is the first one in the complex is located in front of mihrab.

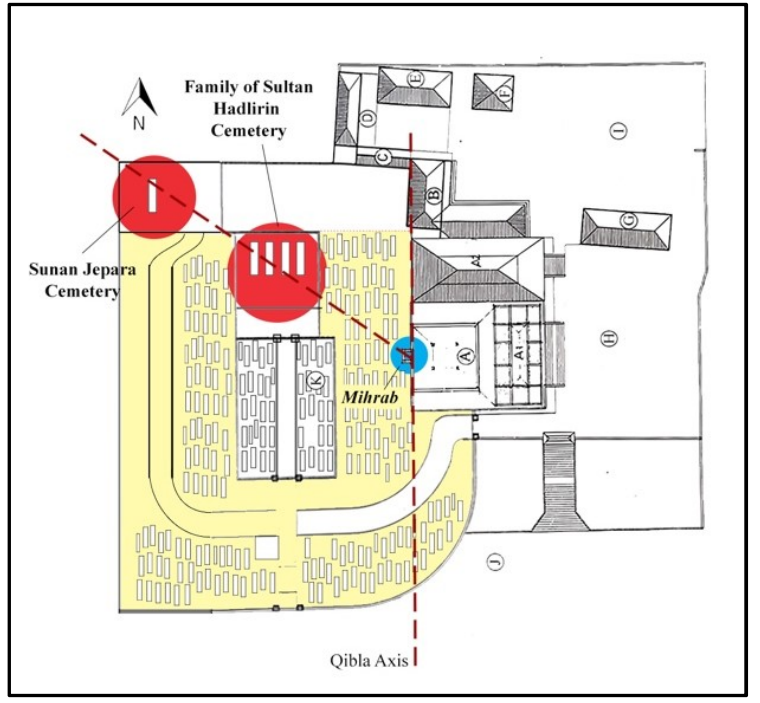

Fig. 12 Location of Cemetery Complex towards Mihrab and Qibla axis, source: auhtor

At the time of pray, there is an ascending process of connecting man to God, and also an descending process from God to man. Placing the cemetery on the west side of mihrab and parallel to the axis of mihrabka'bah describes both the cosmological connection and respecting the death and the important figures in the spread of Islam in Mantingan. Besides to the process of human worship therein, it also has the connection with the environment. The mosque serves as a microcosm of the ka'bah, and the Ka'bah becomes the center and balancing for Muslims around the world, plays a role as a macro cosmos or universe for the whole mosque. There is a continuous process of environment, mosque, and the ka'bah, which are at the center of the world and balancing cosmology.

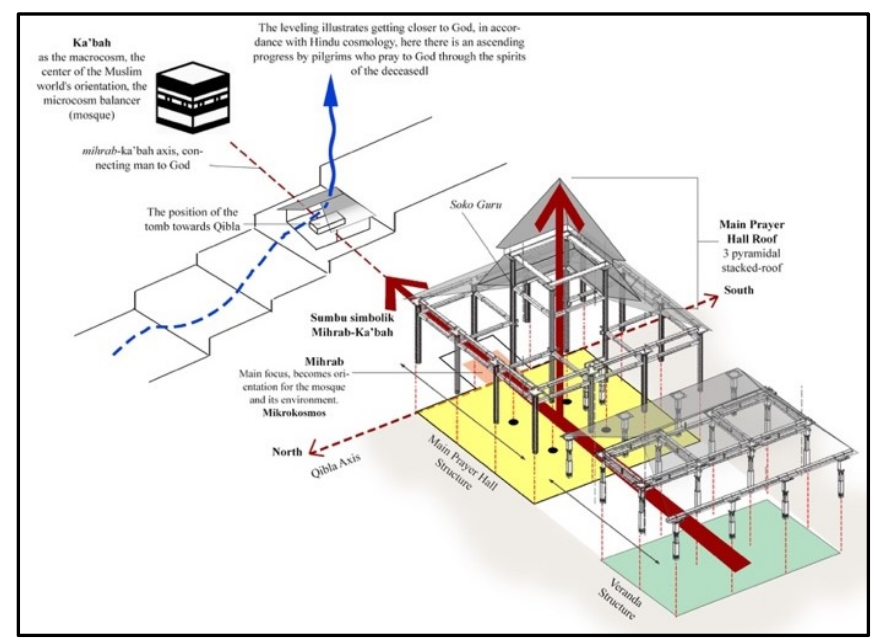

Fig. 13Connection of Mosque, Qibla, and Cemetery according to Cosmology,Ssource: authors 
Depicted in the figure 13 is the process of praying and worshiping in the mosque following the direction of the qibla. This direction describes the celestial forces of the afterlife, and the orientation is straight to follow the axis of mihrab-Ka'bah depicting the terrestrial forces of living man to afterlife.

The Mantingan Mosque and Cemetery Complex has the same arrangement in relation to cosmology that connects nature or built environment, man and God. The contour at the cemetery complex emphasize lower-middle-upper worlds realtion. The verticality of the spatial pattern in the complex show how people relate to God while the horizontal connection provides guidance for man to respect micro- and macro cosmos.

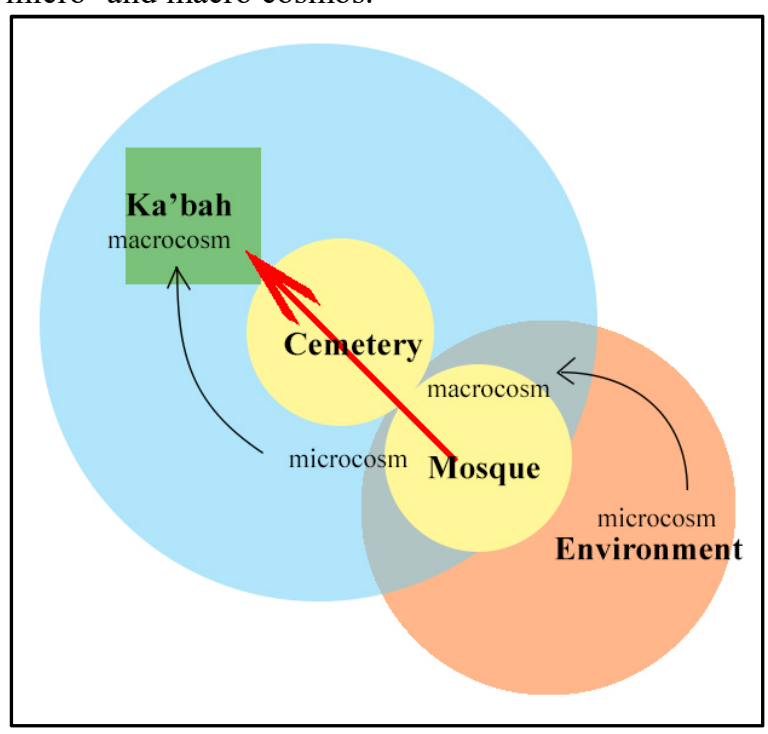

Fig. 14 Illustration of the diagram connection of The Environment-Mosque-Cemetery-Ka'bah as The World Macrocosm.Source: authors.

Muslim need to purify themselves or ablution as an obligatory before praying. One of the efforts done to maintain the availability of water is through building water tank and placing the mosque near a river or a source of water. There is a small river flows on the West side of the Mantingan Mosque that make the current site ideal. Maintaining open space for a mosque is important because this open space becomes rain water catchment area that can maintain the availability of ground water reserves. The cemetery complex gives open space for the Mosque.

\section{Conclusion}

Sustainable architecture shows the close connection between ecologically responsible building design and sustainable development including in traditional environment. The Mantingan Mosque and cemetery complex show some advantage of the wisdom of traditional local building philosophy and techniques, and create cultural and social sustainability.
There are some important aspect of Javanese architecture that are applied at the Mantingan Mosque and cemetery complex. The complex follows Javanese cosmological organization that formed an axis depicting the duality concept in Javanese cosmology. The location of the Mantingan Mosque and cemetery complex is higher than its surrounding emphasize the importance of the complex especially as cultural and spiritual bound from the people of Mantingan. The idea of micro- and macro cosmos connection applied for the complex means the manifestation of culture to the built environment that help culture to sustain changes over time.

The Mantingan Mosque and Cemetery Complex has an important role in application of Javanese cosmology for the city Jepara, especially in the sustainability of cultural values for the city. Although the location of the complex is not at the city center, the historical and cosmological values that exist in the complex bound the community and even help Mantingan to become a tourist destination in Java.

The location of the cemetery is located on the western side of the mosque, parallel to the direction of qibla, forming a straight line from the person doing worship - the cemetery - and towards the macrocosm to the ka'bah. When one prays, the cemetery complex will be in front of him and this becomes a reminder of the afterlife.

The buildings in the complex follow Javanese architecture. There are some benefits of following local architectural principles such as low energy consumption for the building, good cross ventilation and providing open space for the community.

In addition to functioning as a place of worship, the Mantingan Mosque also functions as a place for people activities such as Islamic celebration and rituals and learning the Qur'an. The Mantingan Mosque and cemetery complex also attract tourists that help to sustain the socio, economic and activities of Mantingan.

Authors would like to thank Universities Indonesiafor PITTA Grant No: 2565/UN2.R3.1/HKP.05.00/2018 that supports the research conducted for this paper.

\section{Reference:}

1. Budi, B.S. A Study on the History and Development of the Javanese Mosque, Part 1: A Review of Theory on the Origin of the Javanese Mosque, JAABE, 3 No.1 (2004)

2. Budi, B.S.A Study on the History and Development of the Javanese Mosque, Part 2: The Historical Setting and Role of the Javanese Mosque under the Sultanates, JAABE, 4 No.1 (2005).

3. Budi, B.S. A Study on the History and Development of the Javanese Mosque, Part 3: Typology of the Plan and Structure of the Javanese, JAABE (2006). 
4. Hardiansyah, I. Pengaruh Kosmologi pada Peletakan Makam di Kompleks Mesjid Jawa. JurusanArsitektur, FakultasTeknik - Universitas Indonesia(2005)

5. Prijotomo, J. Ideas and Forms of Javanese Architecture. Yogyakarta: Gadjah Mada University Press (1988)

6. Santoso, Jo. Arsitektur-kota Jawa, Kosmos, Kultur \& Kuasa, Centropolis - MT Perencanaan Universitas Tarumanegara (2008)

7. Sumalyo, Yulianto. Arsitektur Mesjid dan Monumen Sejarah Muslim. Gadjah Mada University Press, Yogyakarta(2000)
8. Tjahjono, Gunawan. Cosmos, Center and Duality in Javanese Architecture Tradition, Symbolic Dimensions of House Shape in Kota Gede and Surrounding. University of California at Berkley (1989)

9. J. Steel, Sustainable Architecture. Principles, Paradigms, and Case Studies 8th Edition. New York: Mcgraw-Hill (1997)

10. TERI. Sustainable Building - Design Manual: Sustainable Building Design Practices. The Energy and Resources Institute (TERI)(2009) 